\title{
Penurunan Kadar Lemak Darah pada Pasien Penyakit Jantung Koroner dengan Pemberian Latihan Beban Intensitas Rendah dan Aktifitas Fisik
}

\author{
Andy Widhiya Bayu Utomo \\ Pendidikan Jasmani, Kesehatan dan Rekreasi, STKIP Modern Ngawi, andystkipmodern@ gmail.com
}

HS Muhammad Nurfatony

Pendidikan Jasmani, Kesehatan dan Rekreasi, STKIP Modern Ngawi, muhammad.nurfatonni@gmail.com

Muhammad Irfan

Pendidikan Jasmani, Kesehatan dan Rekreasi, STKIP Modern Ngawi, irfanpansa123@gmail.com

\begin{abstract}
Abstrak
Penyakit Jantung Koroner (PJK) merupakan salah satu penyakit kardiovaskular yang paling umum terjadi dan menjadi penyebab kematian tertinggi secara global. Penyakit PJK disebabkan gangguan pada fungsi jantung. Penyumbatan pembuluh darah pada awalnya disebebkan peningkatan kadar kolesterol low-density lipoprotein (LDL) darah berlebih dan menumpuk pada dinding arteri. Tujuan penelitian ini adalah mengetahui penurunan kadar lemak darah antara kelompok aktifitas fisik dengan kelompok latihan beban. Metode yang digunakan pada penelitian ini adalah eksperimental laboratorium pre dan post test. Jumlah sampel pada penelitian ini adalah pasien PJK sebanyak 14 orang laki-laki $(n=14)$ dengan rentang usia 55-60 tahun yang dibagi menjadi dua kelompok beranggotakan 7 orang di masing-masing kelompok. Adapun kriteria inklusi adalah (1) pasien PJK berjenis kelamin laki-laki (2) rentang usia 55-60 tahun (3) memiliki indeks massa tubuh normal. Kelompok pertama diberikan latihan beban sejumlah 7 orang, kelompok dua yang berjumlah 7 orang melakukan aktifitas fisik menggambar, menulis, relaksasi, bersosialisasi kelompok, mendengar musik, dan berwisata. Latihan beban dan aktifitas fisik dilakukan selama 60 menit setiap harinya. Hasil penelitian menunjukkan terdapat penurunan yang cukup signifikan terhadap kadar lemak darah pada pasien PJK dengan latihan beban maupun melakukan aktifitas fisik yang telah ditentukan dengan nilai signifikansi $\mathrm{p}<0,05$. Penurunan kadar lemak darah pada kedua perlakuan tersebut dapat dijadikan intervensi pada pasien PJK untuk lebih meningkatkan aktifitas olahraga, dengan melakukan latihan beban dan aktifitas fisik yang ditentukan.
\end{abstract}

Kata kunci: Lemak Darah, Aktifitas Fisik, Latihan Beban

\section{PENDAHULUAN}

Penyakit Jantung Koroner (PJK) atau dikenal juga sebagai Ischaemic Heart Disease merupakan penyakit yang disebabkan penyumbatan salah satu atau beberapa pembuluh darah yang menyuplai aliran darah ke otot jantung. Manifestasi kerusakan dan dampak akut sekaligus fatal dari PJK disebabkan gangguan pada fungsi jantung. Penyumbatan pembuluh darah pada awalnya disebebkan peningkatan kadar kolesterol lowdensity lipoprotein (LDL) darah berlebih dan menumpuk pada dinding arteri (Okumura, 2011).. Kondisi ini berlanjut hingga bertahuntahun dan menyebabkan plak yang menyumbat arteri, sehingga aliran darah terganggu dan juga dapat merusak pembuluh darah, sehingga timbul gejala PJK dalam waktu yang cukup lama (Bickel et al., 2017).

Penyumbatan pada pembuluh darah juga dapat disebabkan oleh penumpukan lemak disertai klot trombosit yang diakibatkan kerusahakan dalam pembuluh darah. Kerusakan pada awalnya berupa plak fibrosa pembuluh darah, namun selanjutnya dapat menyebabkan ulserasi dan pendarahan di bagian dalam pembuluh darah yang menyebabkan penumpukan klot darah. Pada akhirnya, dampak akut skaligus fatal, PJK merupakan penyakit kronis yang memerlukan waktu yang cukup 
lama hingga menimbulkan gejala akibat kerusakan pada pembuluh darah (Deminice, 2016).

Patofisiologi PJK pada umumnya disebabkan penumpukan lemak atau LDL di pembuluh darah. Tetapi kondisi ini dipicu dari beberapa gaya hidup yang tidak sehat seperti kurangnya olahraga dan atau aktifitas fisik, kebiasaan merokok, pola makan tidak sehat serta obesitas. Kurangnya olahraga dan atau aktifitas fisik merupakan faktor risiko terhadap PJK. Sebaliknya beraktifitas fisik cukup secara teratur dapat menurunkan risiko PJK. Secara substansial, beraktifitas fisik secara rutin dapat menurunkan risiko PJK dengan cara meningkatkan kesehatan jantung dan pembuluh darah. Aktifitas fisik biasa pun diketahui dapat mempengaruhi mekanisme metabolisme tubuh serta meningkatkan kadar high-density lipoprotein (HDL) dan dapat menurunkan kadar lemak berlebih dalam darah, meningkatkan metabolisme glukosa dengan cara meningkatkan sensitivitas insulin serta menurunkan kadar lemak berlebih dan tekanan darah tinggi, meski demikian, menfaat dari aktifitas fisik dipengaruhi oleh durasi dan frekuensi dari aktifitas fisik tersebut (Dowson, 2016; Deminice, 2016; Hannibal, 2017).

Aktifitas fisik merupakan salah satu aktifitas tubuh yang tidak memerlukan beban tambahan dari luar tubuh seseorang tersebut, berbeda dengan latihan beban yang juga disebutkan sebagai salah satu olahraga yang mampu menurunkan kadar lemak darah, dengan durasi, frekuensi serta repetisi yang disesuaikan (Okumura, 2011). Namun, beberapa penelitian terkait dengan pengaruh aktifitas fisik dan latihan beban terhadap kadar lemak darah masih belum menemukan durasi, frekuensi dan repetisi latihan yang memberikan dampak signifikan terhadap penurunan kadar lemak darah. Tujuan penelitian ini adalah mengetahui penurunan kadar lemak darah antara kelompok aktifitas fisik dengan kelompok latihan beban (Bickel et al., 2017).

Program latihan beban yang diberikan pada pasien PJK adalah selama 8 minggu, dilakukan 3 hari dalam satu minggu dilakukan pada hari yang tidak berurutan, setiap sesi latihan berlangsung selama 60 menit, pasien melakukan 5 jenis latihan beban, dengan beban $85 \%$ dari beban maksimal yang didapatkan dari satu kali repetisi maksimal. Latihan dilakukan dengan berintensitas rendah, repetisi sebanyak 20 kali dalam 3 set dengan 2 menit istirahat setiap set dan repetisi (Joubert, 2006).

Program aktifitas fisik berlangsung sama yaitu 8 minggu yang dilakukan selama 3 hari dalam satu minggu dengan hari yang tidak berurutan. Kegiatan yang dilakukan kelompo aktifitas fisik ini adalah menggambar, menulis, relaksasi, bersosialisasi kelompok, mendengar musik, dan berwisata (Joubert, 2006; Subasi, 2012; Sanchez, 2015).

\section{METODE}

Penelitian ini bertujuan untuk membandingkan aktifitas fisik dengan latihan beban terhadap penurunan kadar lemak darah pada pasien PJK. Metode yang digunakan pada penelitian ini adalah eksperimental laboratorium pre dan post test. Jumlah sampel pada penelitian ini adalah pasien PJK sebanyak 14 orang laki-laki $(n=14)$ dengan rentang usia 55-60 tahun yang dibagi menjadi dua kelompok beranggotakan 7 orang di masing-masing kelompok.

Adapun kriteria inklusi adalah (1) pasien PJK berjenis kelamin laki-laki (2) rentang usia 55-60 tahun (3) memiliki indeks massa tubuh normal. Kelompok pertama diberikan latihan beban sejumlah 7 orang, kelompok dua yang berjumlah 7 orang melakukan aktifitas fisik menggambar, menulis, relaksasi, bersosialisasi kelompok, mendengar musik, dan berwisata. Latihan beban dan aktifitas fisik dilakukan selama 60 menit setiap harinya. 
Tabel 1. Deskripsi data sampel penelitian

\begin{tabular}{|l|c|c|}
\hline \multirow{2}{*}{ Variabel } & \multicolumn{2}{|c|}{ Mean \pm SD } \\
\cline { 2 - 3 } & Kelompok 1 & Kelompok 2 \\
\hline Usia (tahun) & $56,57 \pm 2,14$ & $57,28 \pm 0,48$ \\
\hline $\begin{array}{l}\text { Berat badan } \\
\left(\mathrm{kg} / \mathrm{m}^{2}\right)\end{array}$ & $60,14 \pm 4,94$ & $61,71 \pm 6,42$ \\
\hline $\begin{array}{l}\text { Tinggi } \\
\text { badan }(\mathrm{cm})\end{array}$ & $166,14 \pm 2,34$ & $167,57 \pm 5,06$ \\
\hline BMI & $21,79 \pm 1,77$ & $21,94 \pm 1,51$ \\
\hline \multicolumn{1}{|c|}{$\mathrm{N}$} & 7 & 7 \\
\hline
\end{tabular}

Tabel 1. adalah data yang menghimpun karakteristik seluruh subjek penelitian. Pada kelompok 1 memiliki rerata usia 56,57 tahun dengan kisaran usia antara 55-60 tahun. Sedangkan pada kelompok 2 memiliki rerata usia 57,28 tahun dengan kisaran usia 56-60 tahun. Berat badan minimal subjek adalah $55 \mathrm{~kg}$ dan berat badan maksimal adalah $71 \mathrm{~kg}$ dengan tinggi badan minimal adalah $158 \mathrm{~cm}$ dan tinggi badan maksimal adalah 173. Nilai minimal dan maksimal berat badan serta tinggi badan menunjukkan subjek penelitian memiliki kriteria IMT normal, pada kelompok 1 memiliki nilai IMT $21,79 \mathrm{~kg} / \mathrm{m}^{2}$ dengan kisaran angka normal $19-23 \mathrm{~kg} / \mathrm{m}^{2}$, pada kelompok 2 memiliki angka IMT masih dalam batas normal yaitu 19$24 \mathrm{~kg} / \mathrm{m}^{2}$.

Prosedur penelitian awal yang dilakukan adalah melakukan pemeriksaan kondisi jantung pasien, pemeriksaan ginjal dan hati, tinggi badan, berat badan, dan indeks massa tubuh. Subjek dibagi menjadi dua kelompok, dengan kelompok pertama adalah kelompok latihan beban, kelompok kedua adalah kelompok aktifitas fisik. Latihan beban dilakukan dengan intensitas rendah yaitu detak jantung tidak lebih dari $50 \%$, setiap sesi latihan berlangsung selama 60 menit, pasien melakukan 5 jenis latihan beban, dengan beban $85 \%$ dari beban maksimal yang didapatkan dari satu kali repetisi maksimal. Latihan dilakukan dengan berintensitas rendah, repetisi sebanyak 20 kali dalam 3 set dengan 2 menit istirahat setiap set dan repetisi. Aktifitas fisik yang dilakukan oleh kelompok dua adalah menggambar, menulis, relaksasi, bersosialisasi kelompok, mendengar musik, dan berwisata.

\section{HASIL}

Tabel 2. menjelaskan rerata dan hasil uji normalitas kadar lemak darah pre test dan post test kelompok 1 dan kelompok 2 serta nilai delta profil lipid. Hasil uji normalitas pre test dan post test pada kelompok 1 dan kelompok 2 berdistribusi tidak normal dengan nilai signifikansi 0,000 dengan nilai normal signifikansi $\mathrm{p}>0,005$. Oleh karena itu maka uji beda berpasangan untuk kelompok 1 dan kelompok 2 menggunakan uji non parametrik yaitu wilcoxon. Hasil uji normalitas pada nilai delta menunjukkan nilai $\mathrm{p}>0,05$ yaitu 0,902 , maka uji beda menggunakan parametrik yaitu independent $t$-test.

Tabel 2. nilai rerata dan standar deviasi kadar lemak darah pre test dan post test

\begin{tabular}{|l|c|c|c|}
\hline \multirow{3}{*}{ Variabel } & \multicolumn{2}{|c|}{ Mean \pm SD } & \multirow{2}{*}{$\mathrm{p}$} \\
\cline { 2 - 3 } & Kelompok 1 & Kelompok 2 & \\
\hline Lipid & \multicolumn{3}{|c|}{} \\
\hline Pre test & $11,95 \pm 2,67$ & $18,98 \pm 11,38$ & 0,000 \\
\hline Post test & $9,65 \pm 1,73$ & $15,45 \pm 12,47$ & 0,000 \\
\hline Delta & $-2,30 \pm 1,17$ & $1.41 \pm 1.27$ & 0,902 \\
\hline \multicolumn{1}{|c|}{$\mathrm{N}$} & 7 & 7 & \\
\hline
\end{tabular}

Berdasarkan uji beda yang dilakukan pada kelompok 1 dapat dilihat pada tabel 3 menunjukkan nilai $\mathrm{p}<0,05$ yaitu 0,018 . Hasil tersebut menunjukkan bahwa terdapat perbedaan yang signifikan terhadap kadar lemak darah sebelum perlakuan dan setelah perlakuan.

Table 3. Hasil uji perbedaan non parametric (Wilcoxon) kelompok 1

\begin{tabular}{|l|c|c|c|}
\hline \multirow{2}{*}{ Variabel } & \multicolumn{2}{|c|}{ Rerata \pm SD } & \multirow{2}{*}{$\mathrm{p}$} \\
\cline { 2 - 3 } & Pre & Post & \\
\hline Lipid \\
\hline Kelompok 1 & $11,95 \pm$ & $9,65 \pm$ & 0,018 \\
\hline
\end{tabular}


$\mu \mathrm{mol} / \mathrm{L}$ 2,67

1,73

Berdasarkan uji perbedaan yang dilakukan pada kelompok 2 dapat dilihat pada tabel 4 mendpatkan hasil nilai $\mathrm{p}<0,05$ yaitu 0,028 . Hasil tersebut menunjukkan bahwa adanya perbedaan yang signifikan terhadap kadar lemak darah sebelum perlakuan dan setelah perlakuan.

Tabel 4. Hasil uji perbedaan non parametric (Wilcoxon) kelompok 2

\begin{tabular}{|l|c|c|c|}
\hline \multirow{2}{*}{ Variabel } & \multicolumn{2}{|c|}{ Mean \pm SD } & \multirow{2}{*}{$\mathrm{p}$} \\
\cline { 2 - 3 } & Pre & Post & \\
\hline Lipid & \multicolumn{2}{|c|}{} \\
\hline Kelompok 2 & $\begin{array}{c}18,98 \pm \\
11,38\end{array}$ & $\begin{array}{c}15,40 \pm \\
9,53\end{array}$ & 0,028 \\
$\mu$ mol/L & \\
\hline
\end{tabular}

Berdasarkan uji independent $t$-test pada tabel 5 diperoleh nilai $\mathrm{p}<0,05$ yaitu 0,000 . Hal ini menunjukkan bahwa terdapat perbedaan yang bermakna setelah perlakuan kelompok 1 dan kelompok 2.

Tabel 5. Hasil uji independent t-test dilihat dari nilai delta variable Lipid

\begin{tabular}{|c|c|c|c|}
\hline \multirow[b]{2}{*}{ Variabel } & \multicolumn{2}{|c|}{ Mean \pm SD } & \multirow[b]{2}{*}{$\mathrm{p}$} \\
\hline & $\begin{array}{c}\text { Kelompok } \\
1\end{array}$ & $\begin{array}{c}\text { Kelompok } \\
2\end{array}$ & \\
\hline $\begin{array}{c}\text { Lipid } \\
\text { Pre and post } \\
\text { test } \mu \mathrm{mol} / \mathrm{L}\end{array}$ & $\begin{array}{c}-2,30 \pm \\
1,17\end{array}$ & $\begin{array}{c}1,41 \pm \\
0,48\end{array}$ & 0,000 \\
\hline $\mathrm{N}$ & 7 & 7 & \\
\hline
\end{tabular}

\section{PEMBAHASAN}

Hasil pemeriksaan pada penelitian ini terkait dengan penurunan kadar lemak darah pasien PJK pada kelompok satu yang melakukan latihan beban maupun kelompok dua yang melakukan aktifitas fisik yang telah ditentukan sama-sama mengalami penurunan pada kadar lemak darah. Beberapa penelitian menyebutkan bahwa dengan melakukan olahraga khususnya latihan beban yang terukur secara teratur dapat mengurangi faktor-faktor risiko penyebab penyakit jantung koroner (PJK) sebagai peringkat teratas penyebab kematian (Cotman et all, 2007).

Beberapa hormon pertumbuhan seperti hormon neurotrophin yang memiliki peran pada saat tubuh beraktifitas, seperti juga sistem saraf yang berasal dari otak, faktor pertumbuhan endothelium vascular, dan kadar insulin, yang kesemuanya memiliki peran penting terhadap fungsi organ dan kesehatan tubuh. Oleh karena itu olahraga maupun aktifitas fisik lain sangat penting khususnya untuk pasien PJK dan seseorang yang memiliki kadar lemak darah tinggi (dyslipidemia). Aktifitas fisik yang teratur dan sistematis mampu menurunkan kadar lemak darah di kalangan lanjut usia (lansia). Penelitian menunjukkan bahwa terjadi penurunan kadar lemak total, trigliserida, LDL dan meningkatkan HDL pada perempuan lanjut usia tanpa gangguan kognitif setelah 8 minggu latihan beban (Fahlman et al., 2012). Terdapat penurunan kadar lemak darah pada penelitian lain terkait dengan pemberian latihan beban pada pasien dyslipidemia, namun nilai penurunannya tidak terlalu signifikan (Vincent et al., 2013, Marques et al., 2019., Joseph et al., 2019).

Salah satu hasil yang terpenting pada penelitian ini adalah terjadi penurunan kadar lemak darah LDL dan trigliserida pada pasien yang melakukan latihan beban maupun aktifitas fisik yang ditentukan. Kurangnya pengendalian pada pasien terkait dengan pola makan dimungkinkan mempengaruhi hasil penelitian ini. Oleh karena itu untuk penelitian selanjuitnya perlu dilakukannya kontrol terhadap pola makan subjek penelitian. Namun demikian, dengan hasil yang di dapat pada aktifitas fisik yang juga dapat menurunkan kadar lemak darah, sudah lebih dari cukup untuk memberikan intervensi pada pasien untuk lebih aktif bergerak melakukan aktifitas fisik 
untuk dapat memiliki gaya hidup yang lebih sehat.

Perbedaan pemberian perlakuan pada kedua kelompok ternyata memiliki dampak yang sama yaitu menurunkan kadar lemak darah, meskipun pada kelompok satu melakukan aktifitas yang lebih berat dibanding dengan kelompok dua. Penting untuk diperhatikan bahwa peningkatan kadar lemak pada seseorang disebabkan karena pola hidup yang kurang sehat, pemilihan makanan yang sembarangan, serta kurangnya aktifitas olahraga yang teratur dan terukur serta terkontrol. Penelitian ini belum cukup mewakili latihan beban dan aktifitas fisik mampu menurunkan kadar lemak darah pada pasien PJK, perlu dilakukannya penelitian lanjut dengan memperhatikan durasi waktu penelitian yang perlu diperpanjang lebih dari dua bulan serta perlu adanya kontrol pada pola makan pasien PJK yang menjadi subjek penelitian.

\section{KESIMPULAN}

Kesimpulan pada penelitian ini adalah terdapat penurunan yang cukup signifikan terhadap kadar lemak darah pada pasien PJK dengan latihan beban maupun melakukan aktifitas fisik yang telah ditentukan dengan nilai signifikansi $\mathrm{p}<0,05$. Penurunan kadar lemak darah pada kedua perlakuan tersebut dapat dijadikan intervensi pada pasien PJK untuk lebih meningkatkan aktifitas olahraga, dengan melakukan latihan beban dan aktifitas fisik yang ditentutkan. Namun aktifitas fisik biasa lebih direkomendasikan untuk dilakukan pasien PJK disbanding dengan latihan beban meskipun dalam intensitas yang rendah. Penelitian selanjutnya lebih disarankan untuk lebih bisa mengontrol pola makan subjek penelitian, karena pola makan tersebut akan mempengaruhi hasil penelitia terkait dengan kadar lemak darah.

\section{DAFTAR PUSTAKA}

Bickel, C., Schnabel, R.B., Zengin, E., Lubos, E., Rupprecht, H., Lackner, K., Proust, C., Tregoues, D., Blankenberg, S., Westermann, D., Sinning, C., (2017)., Homocysteine concentration in coronary artery disease: Influence of three common single nucleotide polymorphisms., Nutrition, Metabolism \& Cardiovascular Diseases., 27, 168175

Cotman, W, Carl., Nicole C. Berchtold., LoriAnn Christie., (2007)., Exercise builds brain health: key roles of growth factor cascades and inflammation., TRENDS in Neurosciences Vol.30 No.9.,

Deminice, Rafael., Riberio, Farias, Diogo., Frajacomo, Tadeu, Travesian, Fernando., (2016)., The Effects of Acute Exercise and Exercise Training on Plasma Homocysteine: A MetaAnalysis., DOI:10.1371/journal.pone.0151653

Dowson, Loren, Samantha., Bowe, John Steven., Crowe, Charles, Timothy., (2016)., A combination of omega-3 fatty acids, folic acid and B-group vitamins is superior at lowering homocysteine than omega-3 alone: a meta-analysis., doi: 10.1016/j.nutres.2016.03.010

Fahlman. M Mariane., Debra. Boardley., Charles P. Lambert., Michael G. Flynn., (2012)., Effects of Endurance Training and Resistance Training on Plasma Lipoprotein Profiles in Elderly Women., Journal of Gerontology: BIOLOGICAL SCIENCES Vol. 57A, No. 2, B54-B60

Hannibal, Luciana., Blom, J, Henk., (2017), Homocysteine and disease: Causal associations or epiphenomenons., Molecular Aspects of Medicine 53, 3642

Joseph. J.O. Lyndon., Stephanie. L. Davey., William. J. Evans., Wayne. W. Cambell., (2019)., Differential Effect of 
Resistance Training on the Body Composition and Lipoprotein-Lipid Profile in Older Men and Women., Metabolism, Vol 48, No 11 (November), 1999: pp 1474-1480

Joubert, M, Lanae., Manore, M, Melinda., (2006)., Exercise, Nutrition, and Homocysteine., International Journal of Sport Nutrition and Exercise Metabolism, 16, 341-361

Marques. E., Carvalho. J., Soares. J.m.c., Marques F., Mota. J., (2019)., Effects of resistance and multicomponent exercise on lipid profiles of older women., Maturitas 63 (2019) 84-88

Okumura, Kenji., Tsukamoto, Hideto., (2011),, Folate in smokers., Clinica Chimica Acta 412, 521-526

Sanchez, Maroto, Beatriz., Lopez Tores, Olga., Gonzalo, Palacios., Gonzales, Gross., (2015)., What do we know about homocysteine and exercise? A review from the literature., doi:10.1515/cclm2015-1040

Subasi, Sevi, Sevgi., Gelecek, Nihal., Aksakoglu, Gazanfer., Ormen, Murat., (2012)., Effects of two different exercise trainings on plasma homocysteine levels and other cardiovascular disease risks., Türk Biyokimya Dergisi (Turkish Journal of Biochemistry-Turk J Biochem)., 37 (3) 303-314

Vincent. R. Kevin., Randy W. Braith., Teodoro Bottiglieri., Heather K. Vincent., David T. Lowenthal., (2013)., Homocysteine and Lipoprotein Levels Following Resistance Training in Older Adults., PREVENTIVE CARDIOLOGY 